\title{
MicroRNA-423 promotes proliferation, migration and invasion and induces chemoresistance of endometrial cancer cells
}

\author{
JIE LI, HUIJIE SUN, TING LIU and JIAN KONG \\ Department of Geriatrics, The First Hospital of Jilin University, Changchun, Jilin 130021, P.R. China
}

Received April 16, 2018; Accepted July 26, 2018

DOI: $10.3892 /$ etm.2018.6710

\begin{abstract}
Altered microRNA expression serves essential roles in tumorigenesis and progression in endometrial cancer. In the present study the effect of miR-423 on proliferation, chemosensitivity, migration and invasion of endometrial cancer cells was examined. A WST-1 assay was used to examine the proliferation of HEC-1B and Ishikawa endometrial cancer cells with either upregulation or downregulation of miR-423, with or without cisplatin treatment. The migration and invasion of HEC-1B and Ishikawa endometrial cancer cells were examined via Transwell migration and Matrigel invasion assays. Protein expression levels, including B cell lymphoma-2 (Bcl-2), Bcl-2 associated X protein, E- and N-cadherin, snail, vimentin, phosphatase and tensin homolog (PTEN) and protein kinase $\mathrm{B}$ (AKT) were examined by western blotting. A caspase-Glo3/7 assay was carried out to evaluate the effect of miR-423 on cisplatin-induced apoptosis in HEC-1B and Ishikawa endometrial cancer cells. Overexpression of miR-423 enhanced the proliferation, and increased migration and invasion in endometrial cancer cells. miR-423 also decreased the sensitivity of endometrial cancer cells following cisplatin treatment. miR-423 inhibited cisplatin-induced apoptosis in endometrial cancer cells by regulation of caspase 3/7 and Bcl-2 expression. Furthermore, the E-cadherin expression was significantly decreased, and the expression of $\mathrm{N}$-cadherin, snail and Vimentin were increased in both HEC-1B cells and Ishikawa cells following overexpression of miR-423. Conversely, downregulation of $\mathrm{miR}-423$ increased the expression of E-cadherin and decreased the expression of $\mathrm{N}$-cadherin, snail and Vimentin. Further experiments demonstrated that the expression levels of PTEN and phosphorylated-AKT in HEC-1B and Ishikawa endometrial cancer cells was decreased and increased, respectively, following aberrant expression of miR-423. miR-423 displayed an important role
\end{abstract}

Correspondence to: Dr Jian Kong, Department of Geriatrics, The First Hospital of Jilin University, 380 Xinmin Avenue, Changchun, Jilin 130021, P.R. China

E-mail: kongjian@aol.com

Key words: microRNA-423, endometrial cancer, apoptosis, protein kinase B, phosphatase and tensin homolog in tumorigenesis and progression in endometrial cancer cells, and may therefore be used as a potential biomarker to predict chemotherapy response and prognosis in endometrial cancer.

\section{Introduction}

Endometrial cancer is the most prevalent malignant gynecological neoplasm in the United States, with 63,230 new cases and 11,350 cases of mortality predicted for 2018 (1). It accounts for $\sim 6 \%$ of all cancers in women. Endometrial cancer arises from the endometrium due to the abnormal growth of cells with the ability to invade or metastasize (2). It occurs frequently in postmenopausal women with a mean age of 60 years at the time of diagnosis (3). Vaginal bleeding or discharge in menopausal women is associated with $~ 90 \%$ of endometrial cancer (4). Patients with endometrial cancer are often diagnosed at an early stage and have a good outcome with $\sim 82 \%$ 5-year relative survival (5). The standard treatment for endometrial cancer includes radical hysterectomy, bilateral salpingo-oophorectomy, abdominopelvic washing and lymph node dissection followed by chemotherapy with or without radiotherapy according to the grade and stage of the disease (6). However, patients with advanced or recurrent endometrial cancer do not typically respond well to the standard treatment (7). In addition, resistance to chemotherapy remains a challenge and limits the success of anticancer treatment. Various mechanisms contribute to chemotherapy resistance including the phosphoinositide 3-kinase/protein kinase B (AKT) pathway (8), apoptotic pathways (9) and hormone receptor signaling pathways (10). Therefore, it is important to find alternative strategies to overcome chemotherapy resistance.

microRNAs (miRNAs or miRs) are $21-23$ nucleotides in length, and are highly conserved non-coding small RNA molecules with the biological ability to induce gene silencing (11). Previous studies have demonstrated that miRNA expression is associated with various biological activities including embryo development, proliferation, differentiation, apoptosis, metabolism and tumorigenesis $(12,13)$. Altered miRNA expression pattern has been demonstrated in endometrial cancer. Hiroki et al (14) demonstrated that miR-34b expression is associated with proliferation and invasion of endometrial cancer cells. Wang et al (15) reported that miR-34a expression was significantly reduced in endometrial cancer tissues and miR-34a suppressed the proliferation, migration and 
invasion by targeting Notch1 in endometrial cancer cells. Tores et al (16) demonstrated that miR-99a, miR-100 and miR-199b levels were increased in serum of patients with endometrioid cancer. These findings indicate that the miRNAs may be used as diagnostic markers in endometrioid cancer.

In the present study the effect of miR-423 in proliferation, invasion, migration and chemoresistance of endometrial cancer cell lines was examined.

\section{Materials and methods}

Cell lines. HEC-1B and Ishikawa cells, human endometrial epithelial cancer cell lines, were obtained from Shanghai Cell Bank, Chinese Academy of Sciences (Shanghai, China). These cells were grown in Dulbecco's modified Eagle's medium (DMEM; Invitrogen; Thermo Fisher Scientific, Inc., Waltham, MA, USA) supplemented with $10 \%$ fetal bovine serum (FBS; Invitrogen; Thermo Fisher Scientific, Inc.), $100 \mathrm{U} / \mathrm{ml}$ penicillin and $100 \mu \mathrm{g} / \mathrm{ml}$ streptomycin (Invitrogen; Thermo Fisher Scientific, Inc.), and cultured at $37^{\circ} \mathrm{C}$ in a humidified atmosphere containing $5 \% \mathrm{CO}_{2}$. When cells reached $70-80 \%$ confluence, both cells were harvested for use in further experiments.

Cell transfection. Lipofectamine 2000 (Invitrogen; Thermo Fisher Scientific, Inc.) was used to transfect miR-423 mimic (100 ng; 5'-GCCTGAGGGGCAGAGAGC-3'), miR-423 inhibitor (100 ng; 5'-ATCTTTGGTGGCCGTAGACCT-3') and scrambled negative control RNAs (100 ng; 5'-GCCTAA CTGTGTCAGAAGGAA-3'; Sigma-Aldrich; Merck KGaA, Darmstadt, Germany) into endometrial cancer cells. The cells were harvested $48 \mathrm{~h}$ following transfection and the expression of miR-423 was detected via reverse transcription-quantitative polymerase chain reaction (RT-qPCR).

$R T-q P C R$. Total RNA was extracted from the transfected endometrial cancer cells using TRIzol reagent (Thermo Fisher Scientific, Inc.) according to the manufacturer's protocol. The miRNA analysis was performed using Taqman MicroRNA Reverse Transcription kit (Thermo Fisher Scientific, Inc.). qPCR was performed as follows: $95^{\circ} \mathrm{C}$ for $10 \mathrm{~min}$, followed by 40 cycles of $95^{\circ} \mathrm{C}$ for $15 \mathrm{sec}$ and $60^{\circ} \mathrm{C}$ for $60 \mathrm{sec}$. The primer sequences used were as follows: miR-423, forward 5'-GCC TGAGGGGCAGAGAGC-3' and reverse 5'-CCACGTGTC GTGGAGTC-3'; and U6, forward 5'-GACTATCATATGCTT ACCGT-3' and reverse 5'-GGGCAGGAAGAGGGCCTAT-3'. U6 was used as an endogenous control to calculate expression of miR-423 in endometrial cells. miRNA expression levels were measured based on the threshold cycle $(\mathrm{Cq})$ and relative expression levels were calculated using the $2^{-\Delta \Delta \mathrm{Cq}}$ method (17).

WST-1 assay. To assess the effect of miR-423 on the proliferation and chemotherapy of endometrial cancer cells, the WST-1 assay (Roche Applied Science, Penzberg, Germany) was performed as described previously (18). Briefly, HEC-1B and Ishikawa cells transfected with miR-423 mimics, miR-423 inhibitor and scrambled negative control RNAs were placed in 96-well plates at a density of $1 \times 10^{4}$ cells/well. The endometrial cells were cultured overnight at $37^{\circ} \mathrm{C}$ and the medium was replaced with DMEM containing different concentration of cisplatin (0, 1, 2 and $4 \mu \mathrm{g} / \mathrm{ml}$; Sigma-Aldrich; Merck KGaA). Endometrial cancer cells were subsequently cultured at $37^{\circ} \mathrm{C}$ in a humidified incubator for 7 days. On alternate days, the medium was removed and $200 \mu 1$ DMEM containing WST-1 (20 $\mu \mathrm{l} /$ well) as added to each well and incubated for at least $60 \mathrm{~min}$ at $37^{\circ} \mathrm{C}$. The absorbance was determined at $490 \mathrm{~nm}$ on a microplate reader (BioTek Instruments, Inc., Winooski, VT, USA). All experiments were performed three times in at least triplicate.

Apoptosis analysis. To examine the effect of miR-423 on cisplatin-induced apoptosis of endometrial cancer cells, the caspase 3/7 activity was performed according to the manufacturer's protocol (Caspase-Glo 3/7 assay systems; Promega Corporation, Madison, WI, USA). The endometrial cancer cells transfected with either miR-423 mimic or scrambled negative control RNAs were seeded in 12-well plates as a density of $3 \times 10^{5} /$ well. The cells were cultured in DMEM overnight at $37^{\circ} \mathrm{C}$ in a humidified incubator, and subsequently, the culture medium was replaced with culture medium containing different concentration of cisplatin $(0,1,2$ and $4 \mu \mathrm{g} / \mathrm{ml})$. Cells were cultured for a further $48 \mathrm{~h}$. Caspase-Glo reagent (Promega Corporation) was added to each well and incubated for $8 \mathrm{~h}$ at room temperature with gentle agitation. The caspase $3 / 7$ activity was measured using $1 \mathrm{~min}$ lag time and $0.5 \mathrm{sec} /$ well read time with a luminometer (Thermo Labsystems, Santa Rosa, CA, USA). All experiments were performed three times in triplicate.

Migration and invasion assays. To determine the impact of miR-423 on migration and invasion of endometrial cells, Transwell migration and invasion assays were performed. For invasion assays, the upper chambers of Transwell plates were coated with Matrigel (BD Biosciences, Franklin Lakes, NJ, USA). HEC-1B cells and Ishikawa cells transfected with either miR-423 mimic or miR-423 inhibitor, were suspended in culture medium without FBS and placed in the upper chamber at a density of $3 \times 10^{4} /$ well. Culture medium containing $7 \%$ FBS was added to the lower chamber. The cells were incubated overnight at $37^{\circ} \mathrm{C}$ in a humidified atmosphere containing $5 \%$ $\mathrm{CO}_{2}$. Remaining cells in the upper chamber were removed with a cotton swab and cells in the lower chamber were stained at room temperature for 2 min with Diff Quik solution. The invaded cells were counted under light microscopy in 5 random visual fields (magnification, x10). The percentage of invasion was expressed as the ratio of invading cells/cell number normalized on day 2 of the growth curve, based on the proliferation assay. Endometrial cancer cells transfected with scrambled negative control RNAs were used as the negative control. All experiments were performed three times in triplicate.

Western blotting. To extract total protein from the transfected endometrial cancer cells, ice-cold radioimmunoprecipitation assay lysis and extraction buffer (Invitrogen; Thermo Fisher Scientific, Inc.) was used to suspend the cells. The protein concentration was measured by bicinchoninic acid assay. The total protein was mixed with loading buffer (Abcam, Cambridge, MA, USA) and boiled for $10 \mathrm{~min}$. Then the protein concentration was measured and separated by $10 \%$ SDS-PAGE 
Table I. Antibodies used in western blotting.

\begin{tabular}{llcc}
\hline Antibody & \multicolumn{1}{c}{ Supplier } & Catalogue no. & Dilution \\
\hline BAX & Cell Signaling Technology, Inc., Danvers, MA, USA & 2772 & $1: 200$ \\
Bcl-2 & Santa Cruz Biotechnology, Inc., Dallas, TX, USA & sc-7382 & $1: 500$ \\
E-cadherin & Cell Signaling Technology, Inc. & 3195 & $1: 200$ \\
N-cadherin & Cell Signaling Technology, Inc. & 4061 & $1: 200$ \\
Snail & Cell Signaling Technology, Inc. & 3879 & $1: 200$ \\
Vimentin & Cell Signaling Technology, Inc. & 5741 & $1: 100$ \\
p-AKT & Abcam, Cambridge, MA, USA & ab3844 & $1: 200$ \\
PTEN & Cell Signaling Technology, Inc. & 9552 & $1: 200$ \\
AKT & Cell Signaling Technology, Inc. & 9272 & $1: 500$ \\
GAPDH & Cell Signaling Technology, Inc. & 2118 & $1: 2,000$
\end{tabular}

Bcl-2, B cell lymphoma-2; BAX, Bcl-2 associated X protein; AKT, protein kinase B; p, phosphorylated; PTEN, phosphatase and tensin homolog.

A

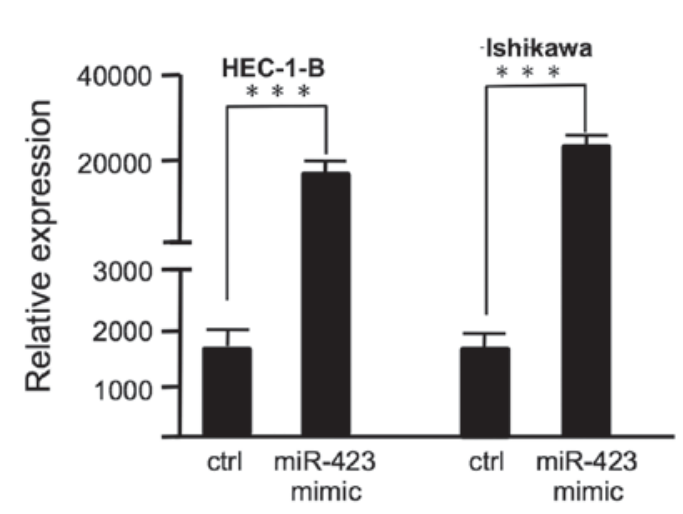

B

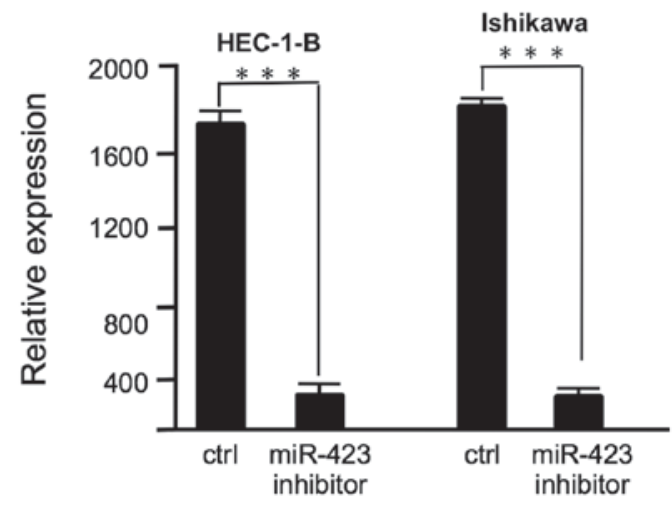

Figure 1. miR-423 levels in HEC-1B and Ishikawa cells following transfection with either miR-423 mimic or miR-423 inhibitor. (A) The miR-423 expression level in endometrial cancer cells transfected with miR-423 mimic. (B) The miR-423 expression level in endometrial cancer cells transfected with miR-423 inhibitor. ${ }^{* * *} \mathrm{P}<0.01$. miR, microRNA; ctrl, control.

and transferred to polyvinylidene difluoride membranes (Sigma-Aldrich; Merck KGaA). Following blocking in 5\% non-fat dry milk in Tris-buffered saline Tween-20 buffer (TBST; Abcam) for $1 \mathrm{~h}$ at room temperature, membranes were incubated with primary antibodies (Table I) overnight at $4^{\circ} \mathrm{C}$ with gentle agitation. Membranes were washed with TBST at least 3 times with gentle agitation followed by incubation with the horseradish peroxidase-conjugated secondary antibody (1:1,000; anti-rabbit IgG; \#7074S; Cell Signaling Technology, Inc., Danvers, MA, USA) for $1 \mathrm{~h}$ at room temperature with gentle agitation. The proteins were visualized using an EasySee Western Blot kit (Beijing Transgen Biotech Co., Ltd., Beijing, China). GAPDH was used as the loading control and iBright imaging systems (CL1000; Thermo Fisher Scientific, Inc.), and Image Lab 6.0 (Bio-Rad Laboratories, Inc., Hercules, CA, USA) was used for densitometry.

Statistical analysis. Data are presented as the mean \pm standard deviation. Statistical analysis was performed using one-way analysis of variance followed by Tukey's post hoc test for comparisons between multiple groups using SPSS 12.0 (SPSS, Inc., Chicago, IL, USA). $\mathrm{P}<0.05$ was considered to indicate a statistically significant difference.

\section{Results}

miR-423 promotes proliferation of endometrial cancer cells and induces cisplatin resistance. To assess the effect of miR-423 on cell proliferation and cisplatin sensitivity, miR-423 mimic or miR-423 inhibitor was transfected to HEC-1B and Ishikawa cells with Lipofectamine 2000, as confirmed by RT-qPCR (Fig. 1). The proliferation of HEC-1B and Ishikawa cells was evaluated using WST-1 assay (Figs. 2-4). The scrambled control RNAs served as negative control. As presented in Fig. 1A, the miR-423 expression level was significantly increased in endometrial cancer cells following transfection with miR-423 mimic. Overexpression of miR-423 significantly improved the proliferation of HEC-1B (Fig. 2A) and Ishikawa cells (Fig. 3E), compared with cells transfected with negative control RNAs. Additionally, the survival rate of 
A

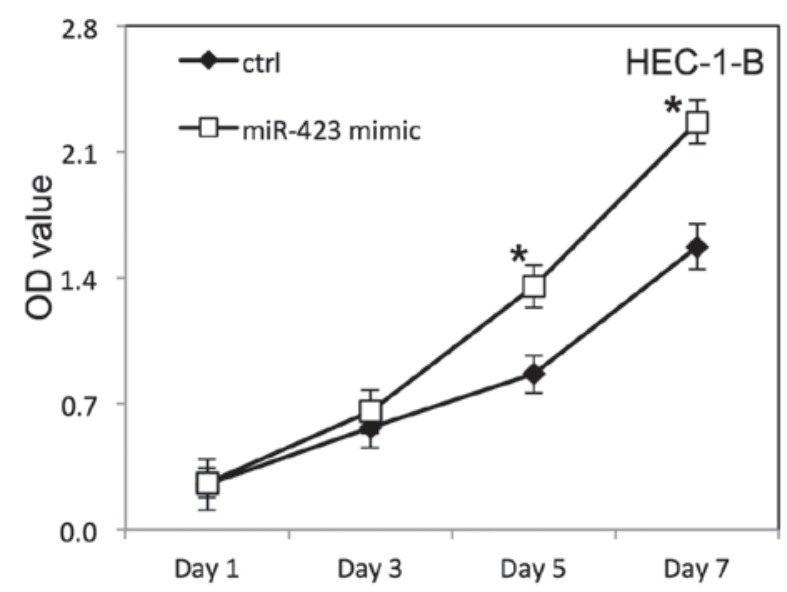

C

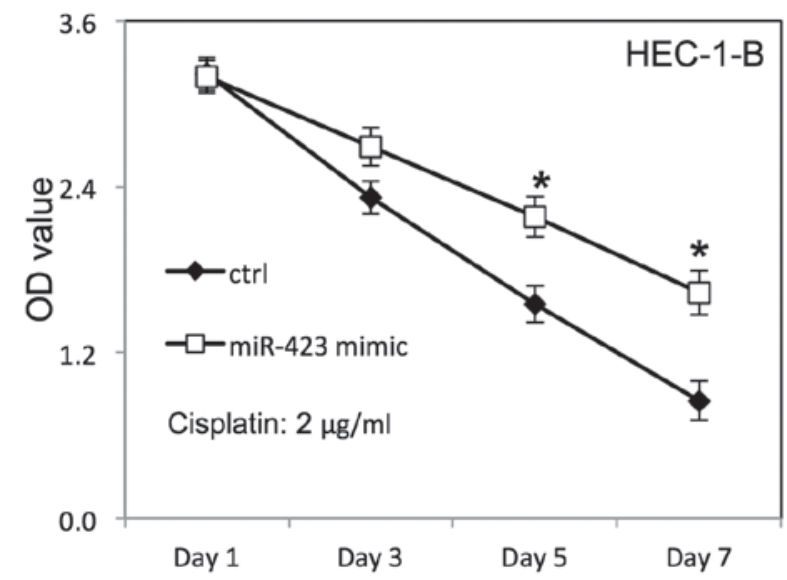

B

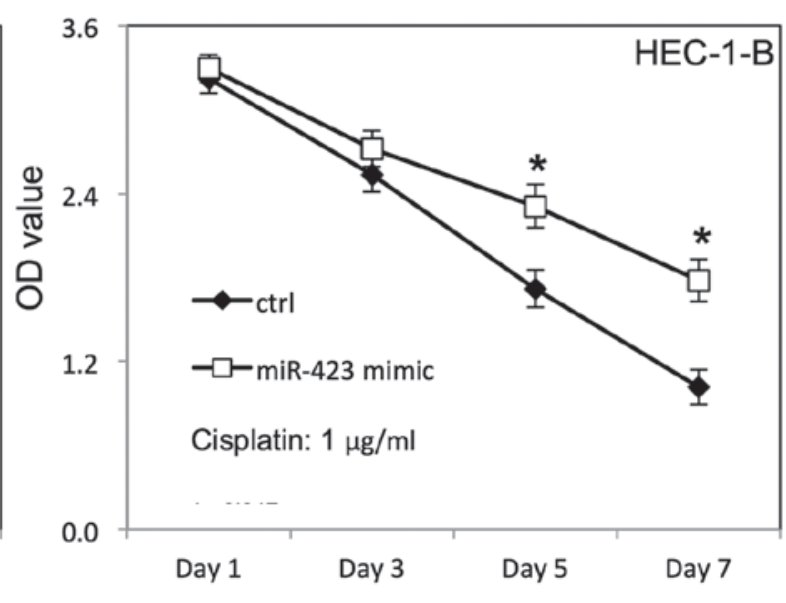

D

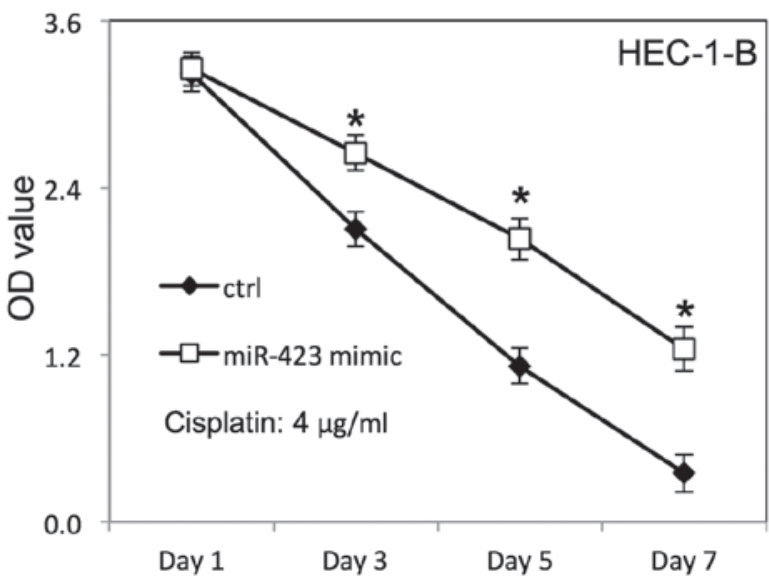

Figure 2. miR-423 promoted the proliferation and survival of HEC-1B cells. (A) The proliferation of HEC-1B cells following miR-423 overexpression. The proliferation of HEC-1B cells transfected with miR-423 mimic with (B) 1, (C) 2 and (D) $4 \mu \mathrm{g} / \mathrm{ml}$ doses of cisplatin. "P<0.05 vs. ctrl. miR, microRNA; OD, optical density; ctrl, control.

HEC-1B (Fig. 2B-D) and Ishikawa cells (Figs. 3F, 4A and B) was increased following overexpression of miR-423 in the presence of cisplatin, compared with the negative control group. The miR-423 expression level was decreased in endometrial cancer cells following transfection with miR-423 inhibitor (Fig. 1B). Downregulation of miR-423 inhibited proliferation of HEC-1B (Fig. 3A) and Ishikawa cells (Fig. 4C), compared with cells transfected with negative control RNAs. Additionally, the survival rate of HEC-1B (Fig. 3B-D) and Ishikawa cells (Fig. 4D-F) was decreased following downregulation of miR-423 in the presence of cisplatin, compared with the negative control group.

miR-423 decreases cisplatin-induced apoptosis of endometrial cancer cells. To examine the function of miR-423 on cisplatininduced apoptosis, transfected endometrial cancer cells were treated with different doses of cisplatin. The apoptosis analysis was carried out via evaluating caspase 3/7 activity. It was demonstrated that upregulation of miR-423 inhibited cisplatin-induced apoptosis by decreasing caspase $3 / 7$ activity (Fig. 5A and B). Western blotting was then performed to further study the expression of apoptosis-associated proteins of transfected endometrial cells in the presence of cisplatin. As presented in Fig. 5C-E, overexpression of miR-423 decreased B cell lymphoma-2 (Bcl-2) associated $\mathrm{X}$ protein (BAX) expression, whereas the $\mathrm{Bcl}-2$ expression was increased in both HEC-1B and Ishikawa cells.

miR-423 increases migration and invasion of endometrial cancer cells. To evaluate the effect of miR-423 on migration and invasion of endometrial cancer cells, invasion and migration assays were performed using transfected HEC-1B (Fig. 6) and Ishikawa cells (Fig. 7) were placed in Transwell chambers with or without Matrigel. It was demonstrated that upregulation of miR-423 enhanced migration and invasion of HEC-1B cells (Fig. 6A-D) and Ishikawa cells (Fig. 7A-D). In contrast, downregulation of miR-423 decreased the migration and invasion of HEC-1B cells (Fig. 6E-H) and Ishikawa cells (Fig. 7E-H).

miR-423 changes the expression of EMT markers and activates AKT pathway in endometrial cancer cells. To further evaluate the molecular mechanisms underlying miR- 423 mediated cell proliferation, migration and invasion in endometrial 
A

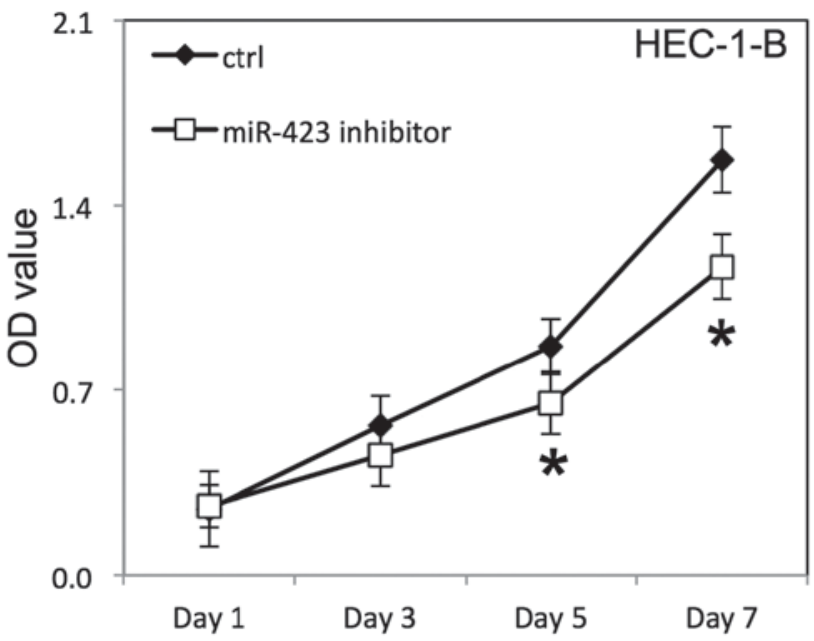

C

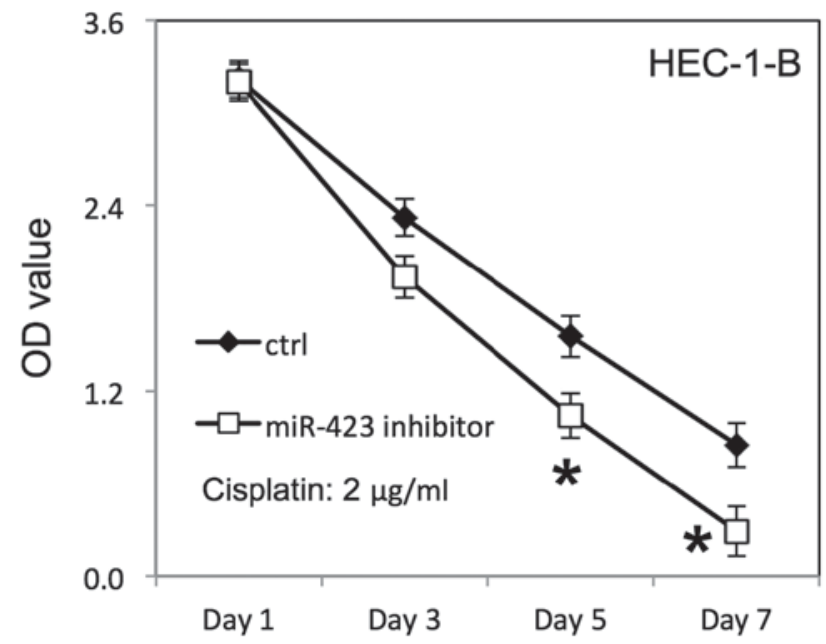

E

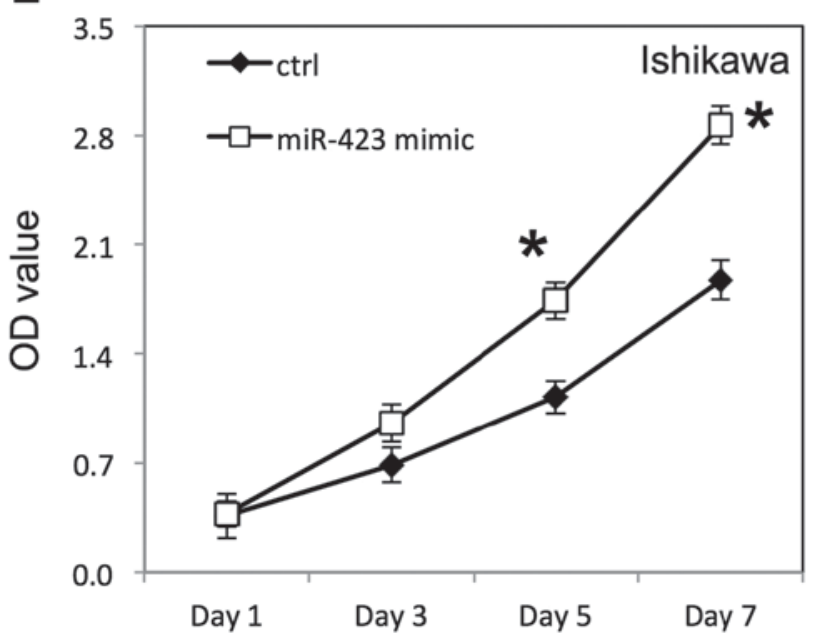

B

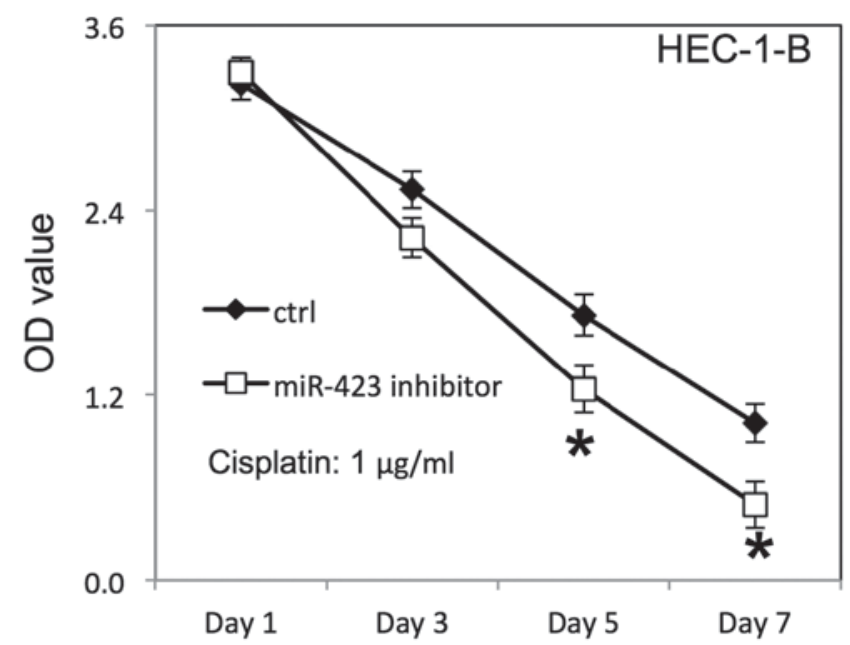

D

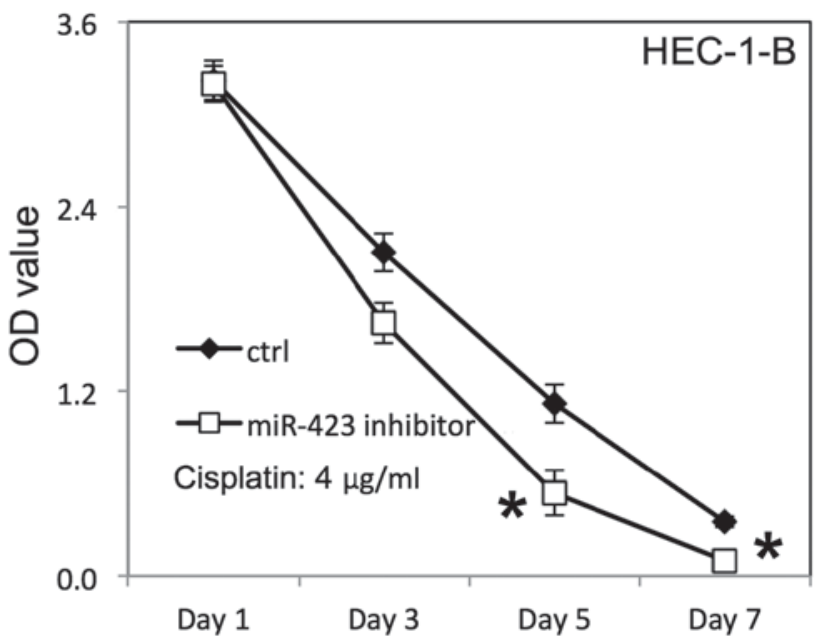

F

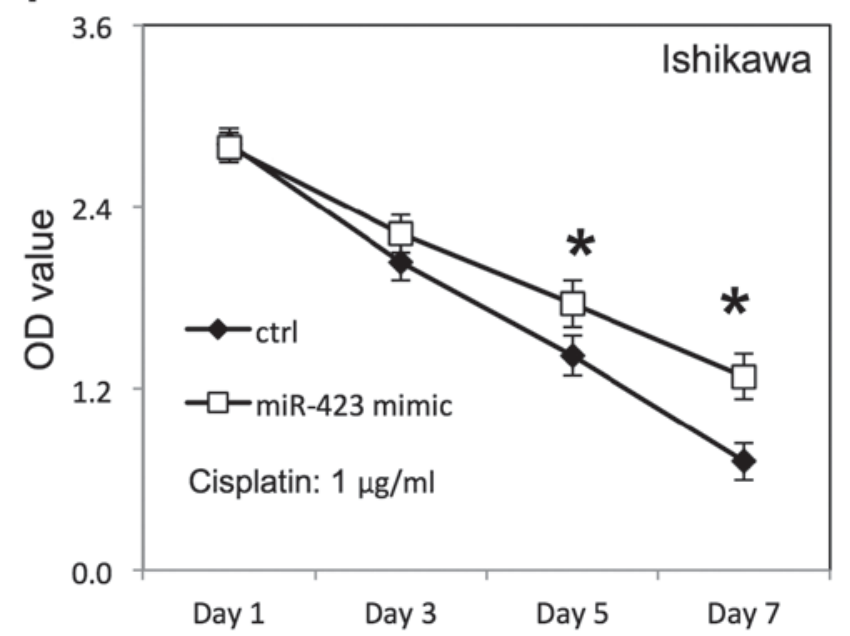

Figure 3. Effect of miR-423 on the proliferation and survival of endometrial cancer cells. (A) Proliferation of HEC-1B cells following miR-423 downregulation. (B-D) Proliferation of HEC-1B cells transfected with miR-423 inhibitor with (B) 1 , (C) 2 and (D) $4 \mu \mathrm{g} / \mathrm{ml}$ doses of cisplatin. (E) The proliferation of Ishikawa cells following miR-423 overexpression. $(\mathrm{F})$ The proliferation of Ishikawa cells transfected with miR-423 mimic with $1 \mu \mathrm{g} / \mathrm{ml}$ cisplatin dosage. ${ }^{*} \mathrm{P}<0.05$ vs. ctrl. miR, microRNA; OD, optical density; ctrl, control.

cancer cells, multiple signaling pathways were examined via western blotting (Figs. 8 and 9). It was demonstrated that the
E-cadherin expression was significantly decreased and the expression of $\mathrm{N}$-cadherin, snail and Vimentin were increased 
A

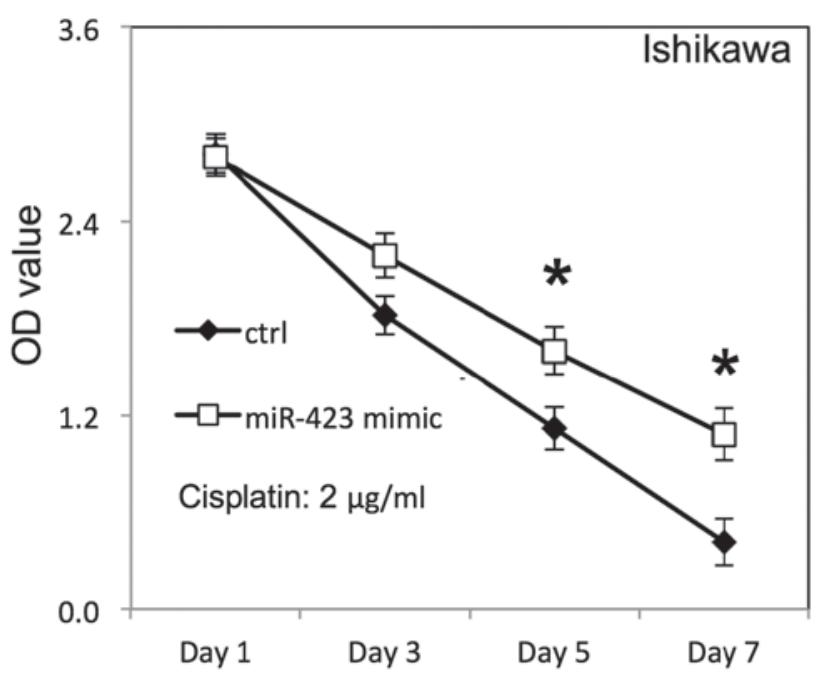

C

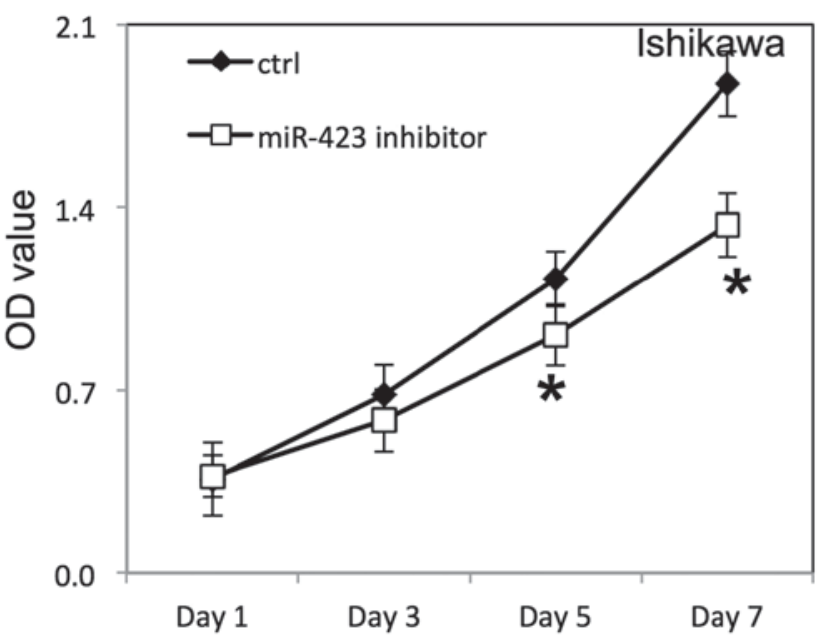

E

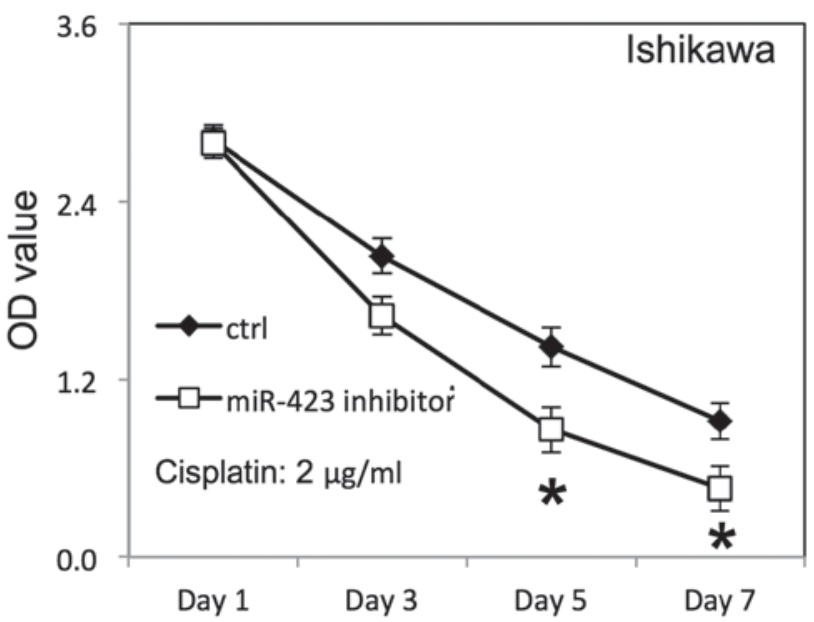

B

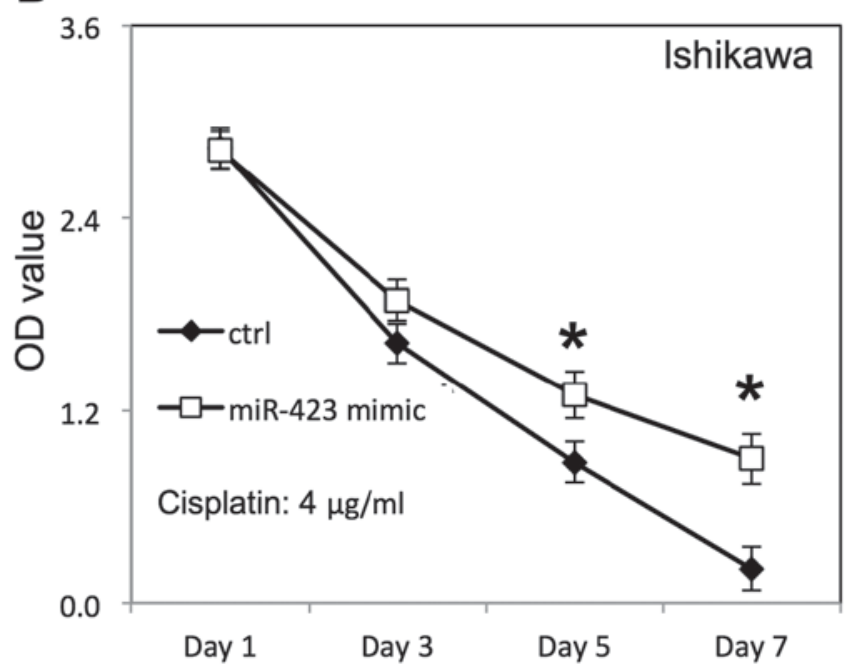

D

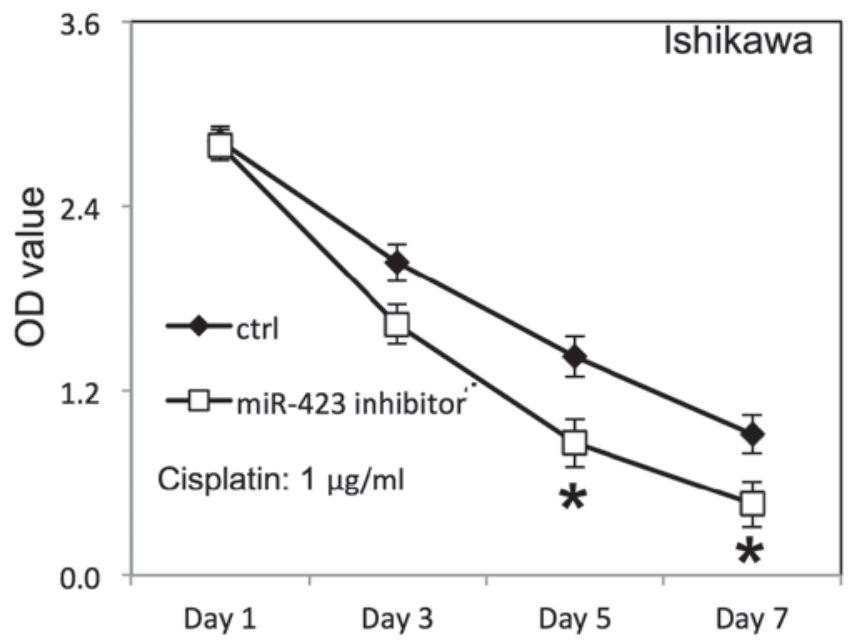

$\mathbf{F}$

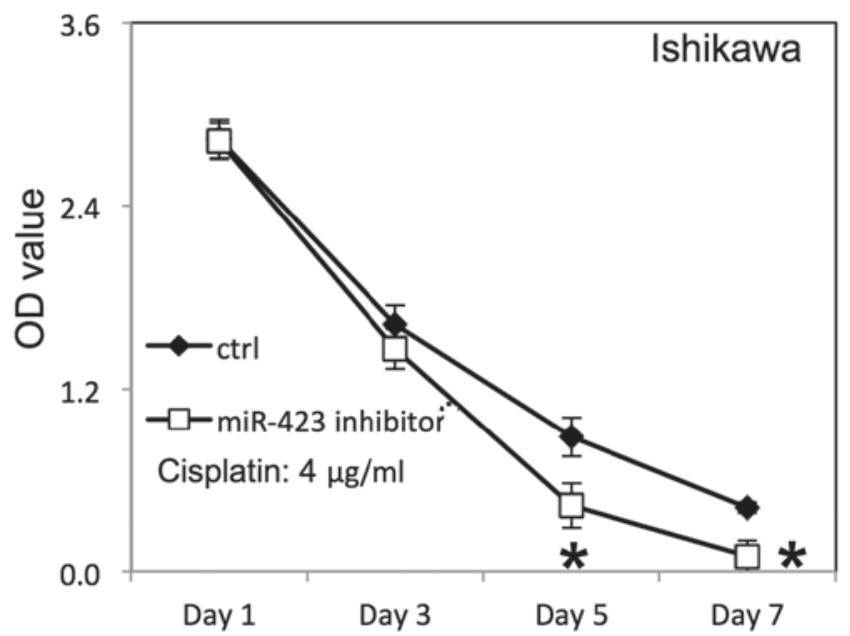

Figure 4. The effect of miR-423 on the proliferation and survival of endometrial cancer cells. The proliferation of Ishikawa cells transfected with (A) 2 and (B) $4 \mu \mathrm{g} / \mathrm{ml}$ doses of cisplatin. (C) The proliferation of Ishikawa cells following miR-423 downregulation. The proliferation of Ishikawa cells transfected with miR-423 inhibitor with (D) 1 , (E) 2 and (F) $4 \mu \mathrm{g} / \mathrm{ml}$ doses of cisplatin. ${ }^{*} \mathrm{P}<0.05$ vs. ctrl. miR, microRNA; OD, optical density; ctrl, control.

in both HEC-1B cells and Ishikawa cells following overexpression of miR-423 (Fig. 8A-C). However, the downregulation of miR-423 increased the expression of E-cadherin, and decreased the expression of $\mathrm{N}$-cadherin, snail and Vimentin in both HEC-1B cells and Ishikawa cells (Fig. 9A-C). Notably, It was demonstrated that miR-423 decreased the phosphatase 
A

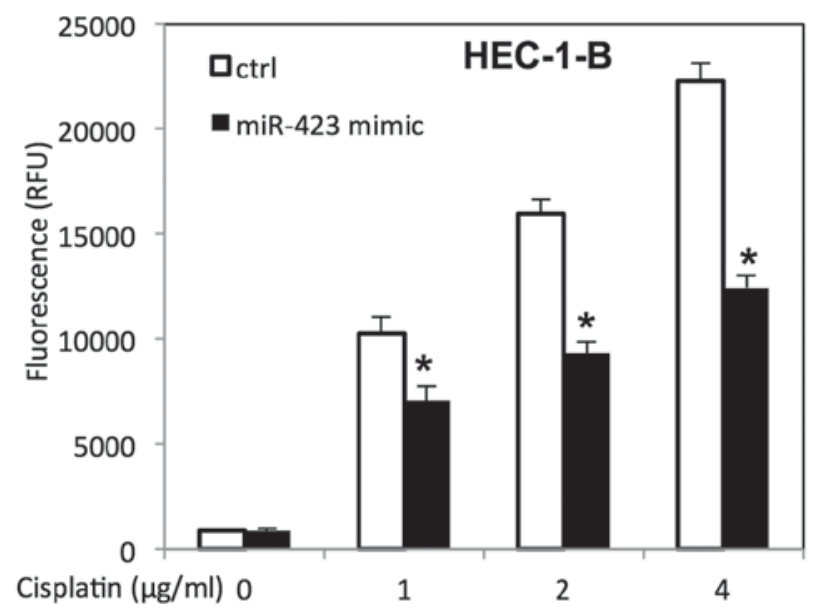

B

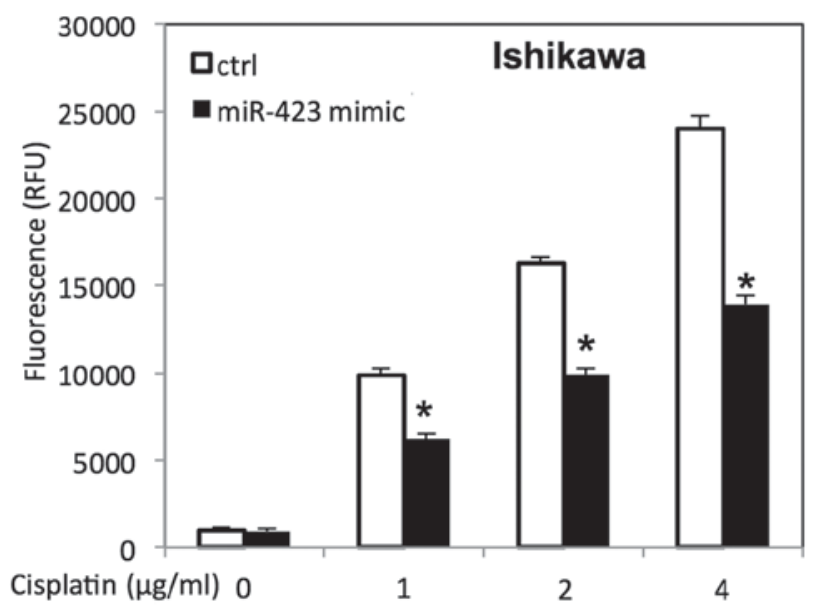

C

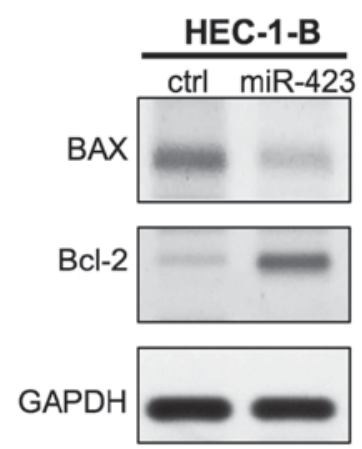

D

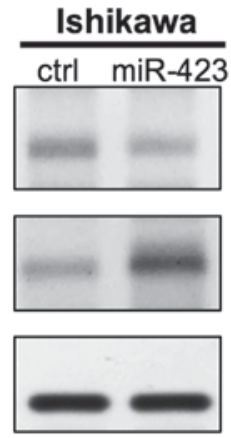

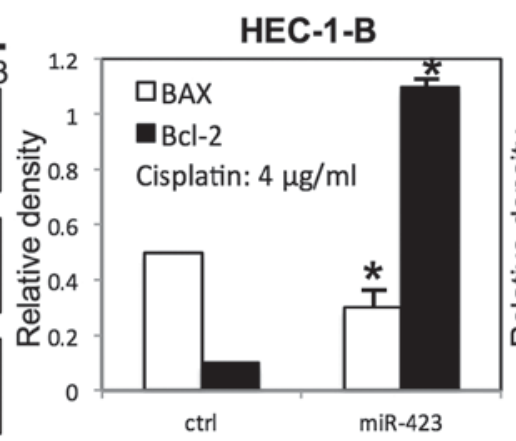

E

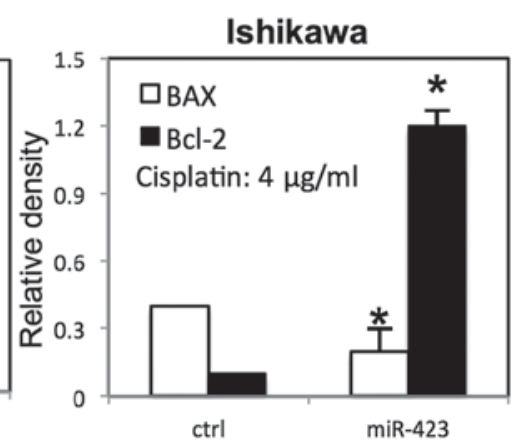

Figure 5. miR-423 inhibits cisplatin-induced apoptosis in endometrial cancer cells. (A) The caspase 3/7 activity in HEC-1B cells transfected with miR-423 mimic following different doses of cisplatin treatment. (B) The caspase 3/7 activity in Ishikawa cells transfected with miR-423 following different doses of cisplatin treatment. (C) The apoptotic proteins levels in HEC-1B cells and Ishikawa cells following 4- $\mu \mathrm{g} / \mathrm{ml}$ cisplatin treatment. The relative expression level of apoptotic proteins in (D) HEC-1B cells and (E) Ishikawa cells following transfection with miR-423 mimic by densitometric analysis. ${ }^{*}<0.05$ vs. cisplatin or ctrl. miR, microRNA; ctrl, control; Bcl-2, B cell lymphoma-2; BAX, Bcl-2 associated X protein.

and tensin homolog (PTEN) expression level, and increased phosphorylated (p)-AKT expression level in HEC-1B and Ishikawa cells (Fig. 8D-F). Meanwhile, the downregulation of miR-423 increased the expression of PTEN, and decreased the expression of $\mathrm{p}-\mathrm{AKT}$ in HEC-1B and Ishikawa cells (Fig. 9D-F).

\section{Discussion}

Growing evidence has demonstrated that miRNA expression serves essential roles in tumorigenesis and progression. miR-423 expression level is upregulated in endometrial cancer cells and involves in carcinogenesis (19). Lin et al (20) reported that miR-423 expression was upregulated in hepatocellular carcinoma and miR-423 promoted cell proliferation by inhibiting tumor suppressor p21Cip1/Waf1 expression. Zhao et al (21) demonstrated that miR-423 enhanced cell proliferation in breast cancer cell lines and acted as a potentially oncogenic role in breast tumorigenesis. Another previous study demonstrated that miR-423 may be an independent marker to predict outcome in patients with breast cancer (22). The present study demonstrated that overexpression of miR-423 enhanced proliferation of endometrial cancer cells, and downregulation of miR-423 inhibited proliferation of endometrial cancer cells. These findings indicated that miR-423 serves a role in the proliferation of endometrial cancer cells.

Cisplatin is a well-known effective anticancer drug and has been used to treat numerous types of malignant tumors including endometrial cancer $(23,24)$. Chemotherapy resistance remains a major challenge, although many efforts have been made to develop novel chemotherapeutic agents (25). Previous studies have demonstrated that chemoresistance may be present prior to therapy or may develop following treatment of recurrent cancer (26). Therefore, it is urgent to identify an alternative strategy to increase chemotherapy sensitivity and reverse resistance. miRNAs have been demonstrated to serve essential roles in chemotherapy sensitivity (27). Yang et al (28) reported that miR-214 promoted cell survival and induced cisplatin resistance by targeting PTEN in ovarian cancer. Kong et al (29) demonstrated that overexpression of miR-155 promoted BT-474 breast cells resistant to paclitaxel, VP16 and doxorubicin, and downregulation of miR-155 sensitized HS578T cells to these drugs. Yu et al (30) reported that overexpression 

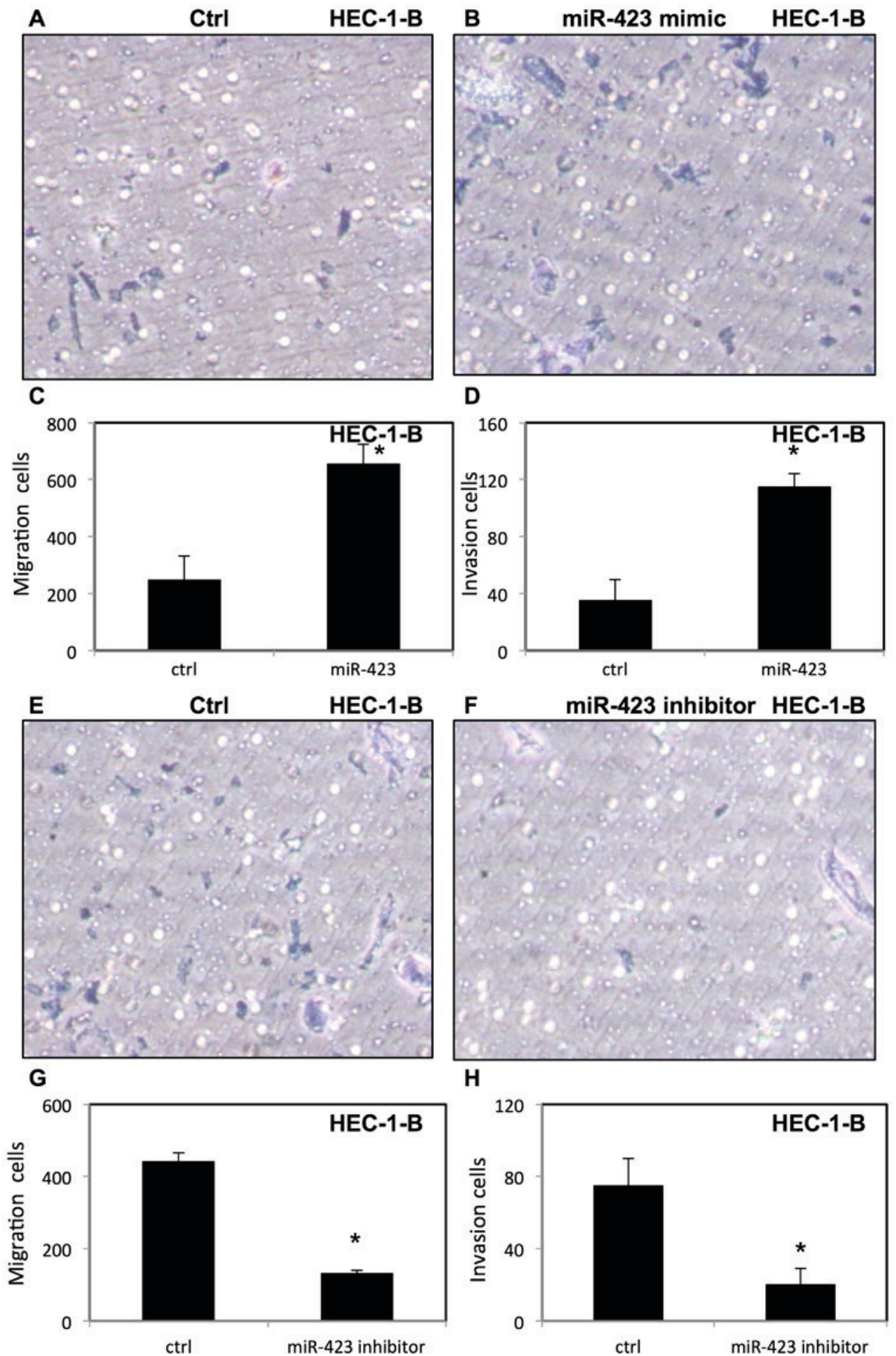

Figure 6. (A-H) Effect of miR-423 on migration and invasion of HEC-1B cells. Compared with (A) the control group, miR-423 increases invasion of HEC-1B cells (B and D). (C) Graph indicates that miR-423 increased migration of HEC-1B cells. Compared with (E) the control group, the invasion of HEC-1B cells was decreased following treatment with miR-423 inhibitor ( $\mathrm{F}$ and $\mathrm{H})$. (G) Graph indicates that miR-423 inhibitor decreased migration of HEC-1B cells. All experiments were performed three times in triplicate. ${ }^{*} \mathrm{P}<0.05$ vs. crtl. miR, microRNA; ctrl, control.

of miR-17/20 increased doxorubicin-induced apoptosis in MCF-7 breast cancer cells by targeting AKT1. The present study demonstrated that overexpression of miR-423 increased the survival of endometrial cancer cells following cisplatin treatment. These results suggested that miR-423 induces drug resistance of endometrial cancer cells. By apoptosis analysis, it was demonstrated that the upregulation of miR-423 decreases the cisplatin-induced apoptosis of endometrial cancer cells. In addition, overexpression of miR-423 increased $\mathrm{Bcl}-2$ and decreased BAX expression levels in endometrial cancer cells. Notably, the survival rate of HEC-1B and Ishikawa cells was decreased following downregulation of miR-423 in the presence of cisplatin, compared with the negative control group. These findings indicated that miR-423 increased the survival 

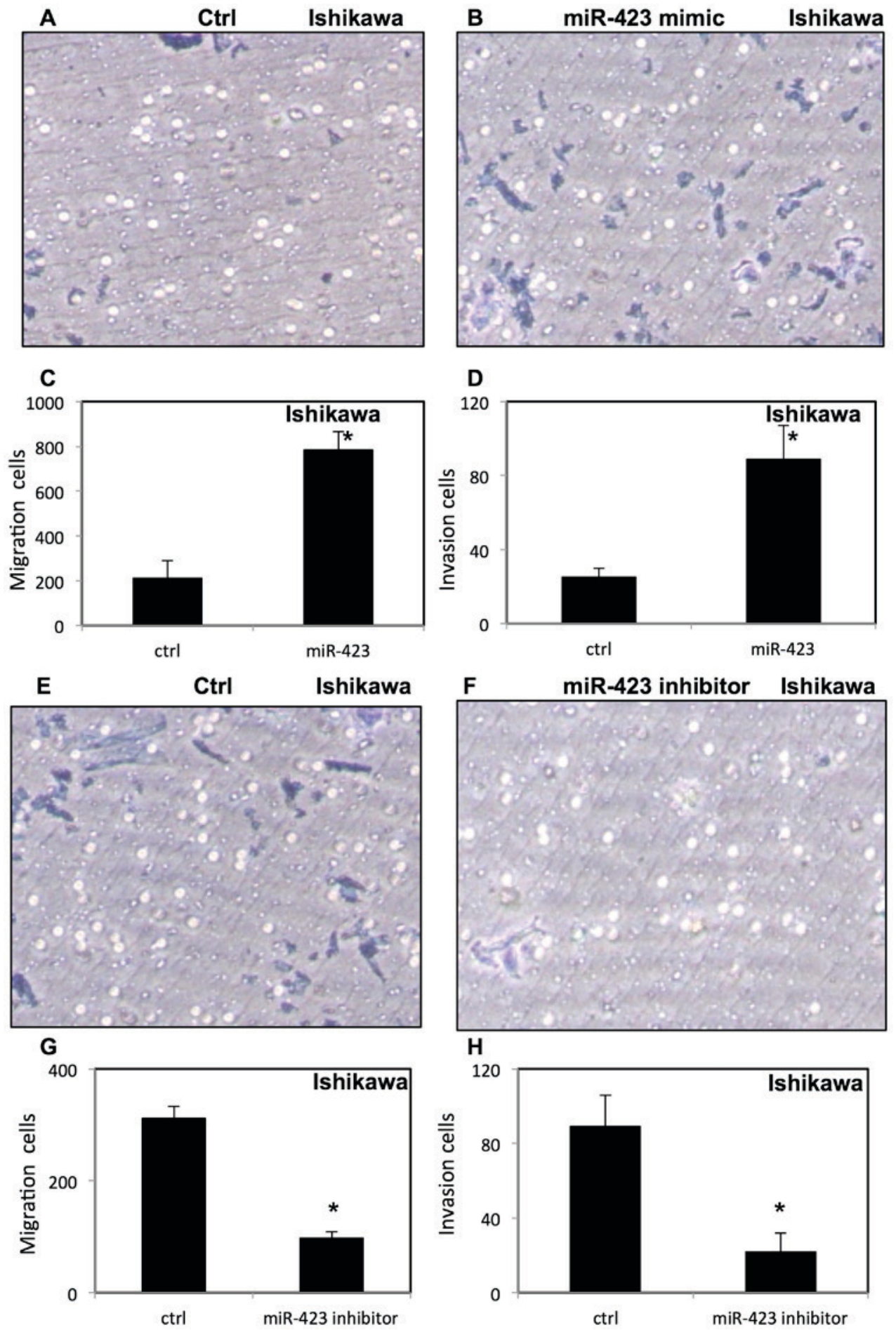

Figure 7. (A-H) The effect of miR-423 on migration and invasion of Ishikawa cells. Compared with (A) the control group, miR-423 increases invasion of Ishikawa cells (B and D). (C) Graph indicates that miR-423 increased migration of Ishikawa cells. Compared with (E) the control group, the invasion of HEC-1B cells was decreased following treatment with miR-423 inhibitor $(\mathrm{F}$ and $\mathrm{H})$. $(\mathrm{G})$ Graph indicates that miR-423 inhibitor decreased migration of Ishikawa cells. All experiments were performed three times in triplicate. ${ }^{*} \mathrm{P}<0.05$ vs. ctrl. miR, microRNA; ctrl, control.

rate of HEC-1B and Ishikawa cells following treatment with cisplatin via inhibiting apoptosis. These results indicated that miR-423 may serve an important role in conferring chemosensitivity to endometrial cancer cells.

Epithelial-mesenchymal transition (EMT) is a biological process that allows epithelial cells to lose their epithelial characteristics and acquire a mesenchymal phenotype. EMT serves critical roles in motility, invasiveness and resistance to apoptosis of cancer cell (31). Recent studies demonstrated that miR-200 family members inhibited EMT by directly targeting zinc finger E-box binding homeobox (ZEB)1 and ZEB2 (32). It was demonstrated in the present study that overexpression of miR-423 increased migration and invasion in endometrial cancer cells via Transwell migration and invasion assays. In contrast, knockdown of miR-423 decreased the migration and invasion of endometrial cancer cells. As detailed above, 
A

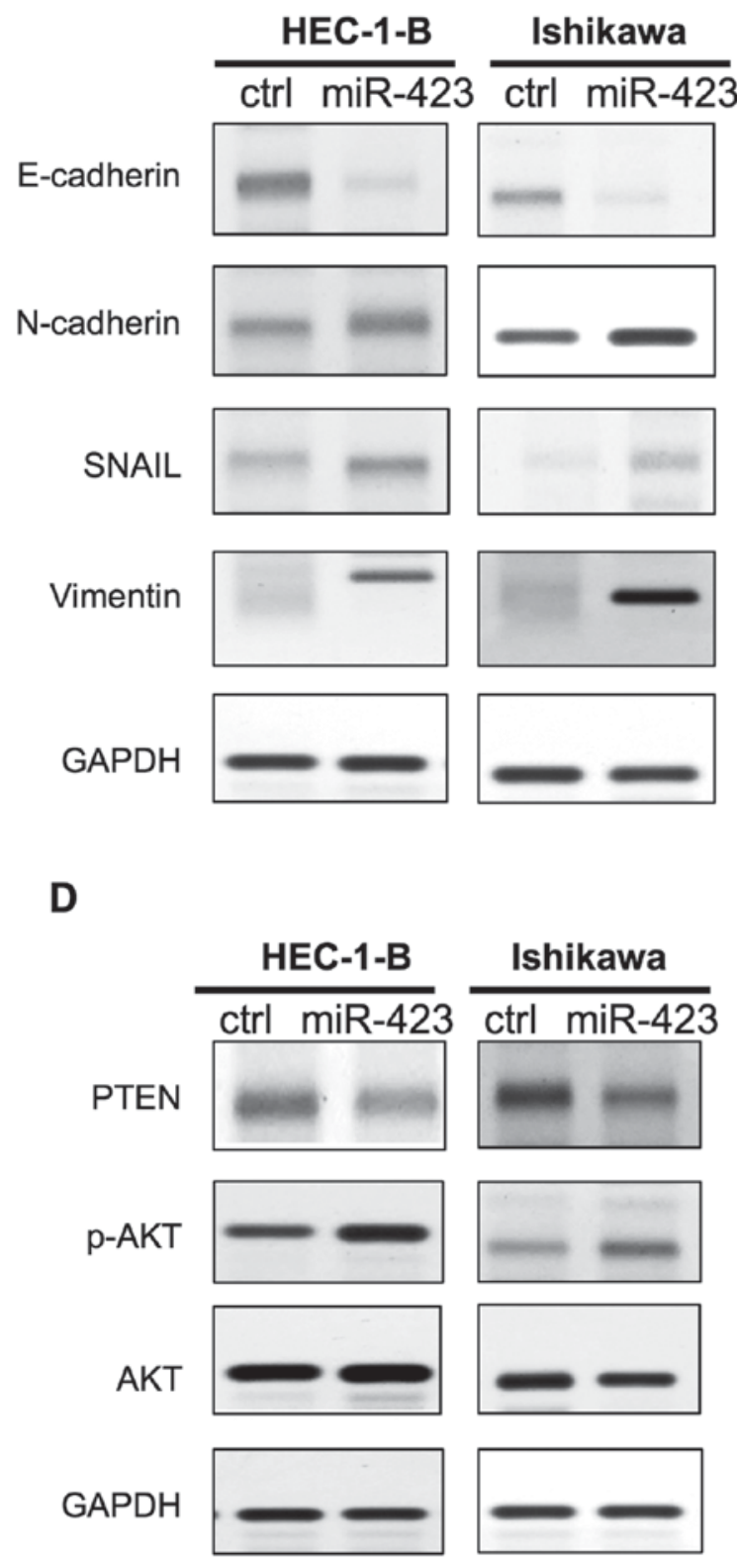

B

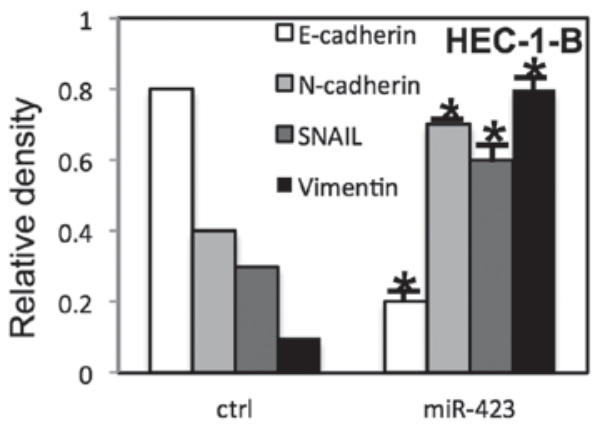

C

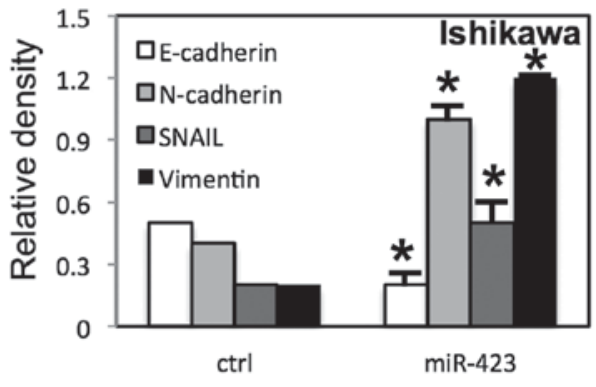

E

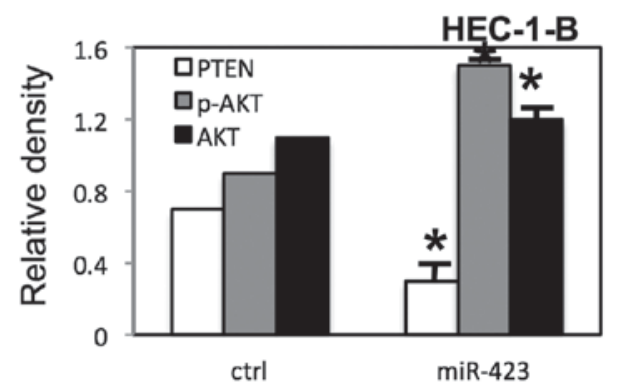

$\mathbf{F}$

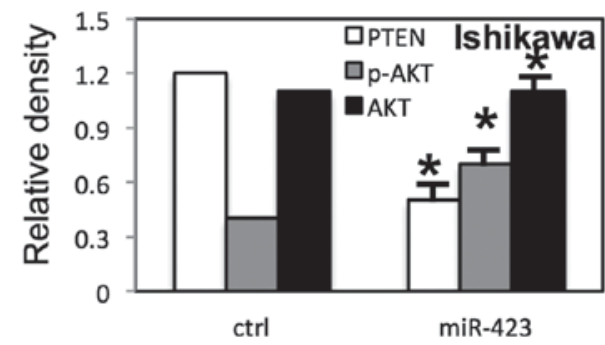

Figure 8. miR-423 affected EMT protein expression and activated AKT expression in endometrial cancer cells. (A) The expression of EMT proteins in HEC-1B and Ishikawa cells following transfection with miR-423 mimic. The relative expression level of EMT proteins on (B) HEC-1B and (C) Ishikawa cells following transfection with miR-423 mimic, identified via densitometric analysis. (D) The expression of p-AKT, AKT and PTEN in HEC-1B and Ishikawa cells following transfection with miR-423 mimic. The relative expression level of proteins on (E) HEC-1B and (F) Ishikawa cells following transfection with miR-423 mimic, identified via densitometric analysis. ${ }^{*} \mathrm{P}<0.05$ vs. ctrl. miR, microRNA; EMT, epithelial-mesenchymal transition; AKT, protein kinase B; p, phosphorylated; PTEN, phosphatase and tensin homolog; ctrl, control.

miR-423 promoted proliferation and inhibited apoptosis of endometrial cancer cells. Although the ratio of invading cells to the total cell number was normalized on day 2 of the growth curve, there is a possibility that the invasion of endometrial cancer cells, at least to some extent, was affected by miR-423 associated proliferation or apoptosis. Therefore, further experiments were performed to explore the effect of miR-423 on expression of EMT-associated proteins in endometrial cancer cells. It was demonstrated that miR-423 inhibited E-cadherin expression and promoted the expression of $\mathrm{N}$-cadherin, snail and Vimentin in endometrial cancer cells. The present study indicated that the expression level of miR-423 is associated with endometrial cancer progression.

PTEN is a well-known tumor suppressor gene in human cancer and regulates multiple biological processes including apoptosis, cell proliferation, invasion, adhesion and metabolism (33). PTEN negatively regulates AKT activity through the dephosphorylation of phosphatidylinositol-trisphosphate (PIP3) to PIP2 (34). PTEN mutations have been reported in $55 \%$ of precancerous lesions, up to $80 \%$ of endometrioid 
A

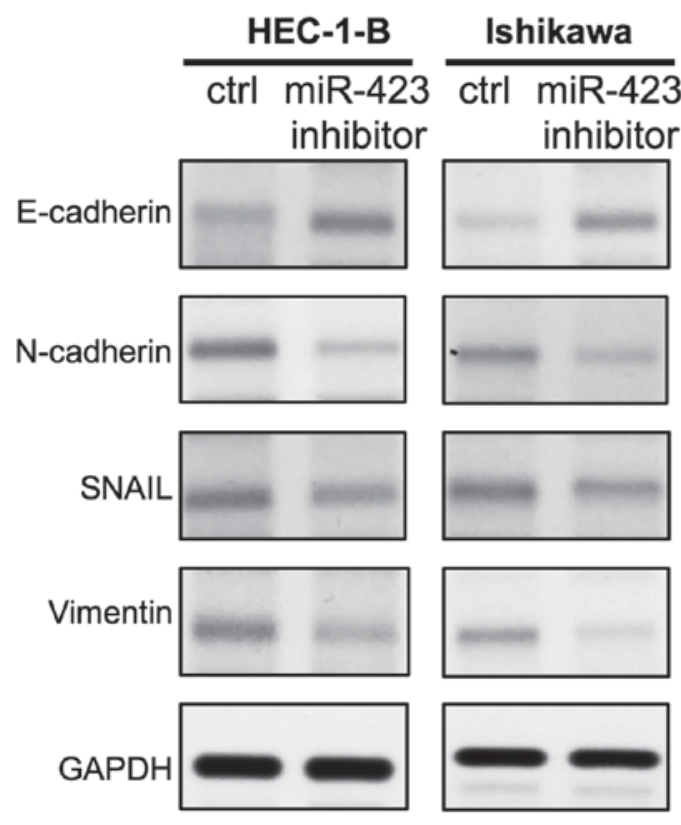

D

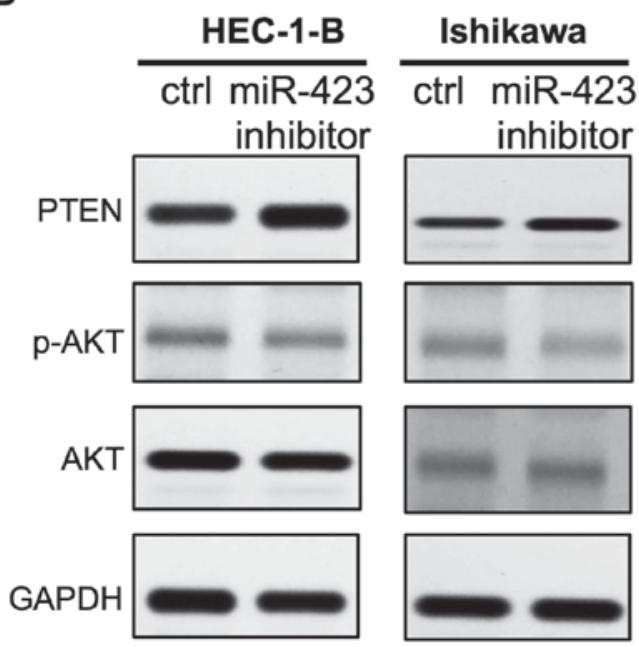

B
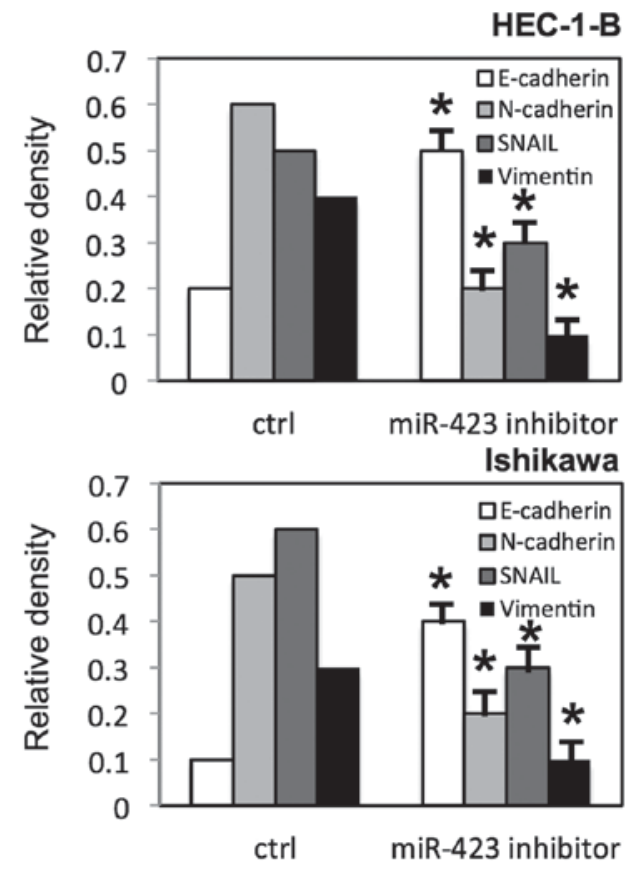

E

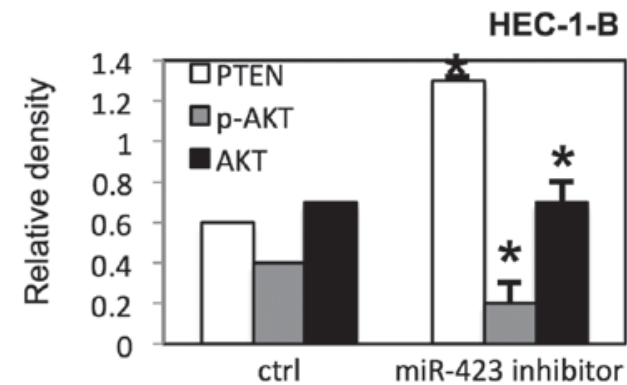

F

Ishikawa

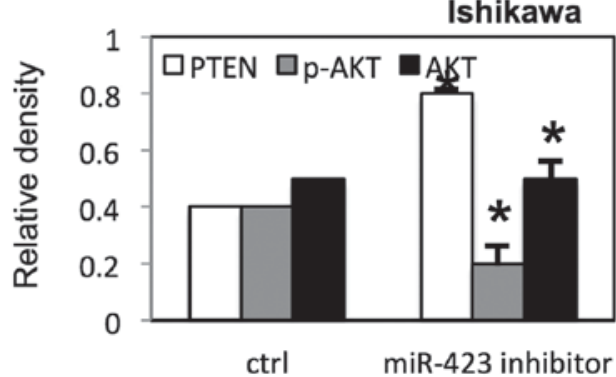

Figure 9. Downregulation of miR-423 affected EMT protein expression and inhibited AKT expression in endometrial cancer cells. (A) The expression of EMT proteins in HEC-1B and Ishikawa cells following transfection with miR-423 inhibitor. The relative expression level of EMT proteins on (B) HEC-1B and (C) Ishikawa cells following transfection with miR-423 inhibitor, identified via densitometric analysis. (D) The expression of p-AKT, AKT and PTEN in HEC-1B and Ishikawa cells following transfection with miR-423 inhibitor. The relative expression level of proteins on (E) HEC-1B and (F) Ishikawa cells following transfection with miR-423 inhibitor, identified via densitometric analysis. * $\mathrm{P}<0.05$ vs. ctrl. miR, microRNA; EMT, epithelial-mesenchymal transition; AKT, protein kinase B; p, phosphorylated; PTEN, phosphatase and tensin homolog; ctrl, control.

endometrial cancer and up to $90 \%$ of high-grade tumors (35). Loss of PTEN and activation of AKT are associated with resistance to small molecule compound treatment in endometrial cancer. It was demonstrated that miR-423 decreased the PTEN expression level, and increased the p-AKT expression level in endometrial cancer cells. These data suggested that miR-423 regulated proliferation of endometrial cancer cells by targeting the AKT signaling pathway. Further studies are required to demonstrate the molecular mechanism.
In conclusion, miR-423 serves important roles in tumorigenesis and malignant progression of endometrial cancer. The present study indicates that miR-423 may be used as a potential biomarker to predict the chemotherapy response and prognosis in endometrial cancer.

\section{Acknowledgements}

Not applicable. 


\section{Funding}

No funding was received.

\section{Availability of data and materials}

The datasets used and/or analyzed during the present study are available from the corresponding author on reasonable request.

\section{Authors' contributions}

JL performed the experiments. HS and TL performed data analysis. JK designed the project. All authors read and approved the final version of the manuscript.

\section{Ethics approval and consent to participate}

Not applicable.

\section{Patient consent for publication}

Not applicable.

\section{Competing interests}

The authors declare that they have no competing interests.

\section{References}

1. Siegel RL, Miller KD and Jemal A: Cancer statistics, 2018. CA Cancer J Clin 68: 7-30, 2018.

2. $\mathrm{Xu} Y Y, \mathrm{Wu} H J, \mathrm{Ma} H D, \mathrm{Xu}$ LP, Huo $\mathrm{Y}$ and Yin LR: MicroRNA-503 suppresses proliferation and cell-cycle progression of endometrioid endometrial cancer by negatively regulating cyclin D1. FEBS J 280: 3768-3779, 2013.

3. Prat J: Pathology of cancers of the female genital tract. Int J Gynaecol Obstet 131 (Suppl 2): S132-S145, 2015.

4. Jin J: Vaginal and urinary symptoms of menopause. JAMA 317: $1388,2017$.

5. Dinkelspiel HE, Wright JD, Lewin SN and Herzog TJ: Contemporary clinical management of endometrial cancer. Obstet Gynecol Int 2013: 583891, 2013.

6. Colombo N, Preti E, Landoni F, Carinelli S, Colombo A, Marini C and Sessa C; ESMO Guidelines Working Group: Endometrial cancer: ESMO clinical practice guidelines for diagnosis, treatment and follow-up. Ann Oncol 24 (Suppl 6): vi33-vi38, 2013

7. Davidson BA, Foote J, Clark LH, Broadwater G, Ehrisman J, Gehrig P, Graybill W, Alvarez Secord A and Havrilesky LJ: Tumor grade and chemotherapy response in endometrioid endometrial cancer. Gynecol Oncol Rep 17: 3-6, 2016.

8. West KA, Castillo SS and Dennis PA: Activation of the PI3K/Akt pathway and chemotherapeutic resistance. Drug Resist Updat 5: 234-248, 2002

9. Mohammad RM, Muqbil I, Lowe L, Yedjou C, Hsu HY, Lin LT, Siegelin MD, Fimognari C, Kumar NB, Dou QP, et al: Broad targeting of resistance to apoptosis in cancer. Semin Cancer Biol 35 (Suppl): S78-S103, 2015.

10. Johnston SR: Enhancing endocrine therapy for hormone receptor-positive advanced breast cancer: Cotargeting signaling pathways. J Natl Cancer Inst 107: pii: djv212, 2015.

11. Catalanotto C, Cogoni C and Zardo G: MicroRNA in control of gene expression: An overview of nuclear functions. Int J Mol Sci 17: pii: E1712, 2016

12. Macfarlane LA and Murphy PR: MicroRNA: Biogenesis, function and role in cancer. Curr Genomics 11: 537-561, 2010.

13. Pillai RS: MicroRNA function: Multiple mechanisms for a tiny RNA? RNA 11: 1753-1761, 2005.
14. Hiroki E, Suzuki F, Akahira J, Nagase S, Ito K, Sugawara J, Miki Y, Suzuki T, Sasano H and Yaegashi N: MicroRNA-34b functions as a potential tumor suppressor in endometrial serous adenocarcinoma. Int J Cancer 131: E395-E404, 2012.

15. Wang Z, Wang W, Huang K, Wang Y, Li J and Yang X: MicroRNA-34a inhibits cells proliferation and invasion by downregulating Notch1 in endometrial cancer. Oncotarget 8: 111258-111270, 2017.

16. Torres A, Torres K, Pesci A, Ceccaroni M, Paszkowski T, Cassandrini P, Zamboni G and Maciejewski R: Deregulation of miR-100, miR-99a and miR-199b in tissues and plasma coexists with increased expression of mTOR kinase in endometrioid endometrial carcinoma. BMC Cancer 12: 369, 2012.

17. Livak KJ and Schmittgen TD: Analysis of relative gene expression data using real-time quantitative PCR and the 2(-Delta Delta C(T)) method. Methods 25: 402-408, 2001.

18. Riss TL, Moravec RA, Niles AL, et al: Cell viability assays, In: Sittampalam GS, Coussens NP, Brimacombe K, et al, (eds). Assay Guidance Manual. Bethesda (MD), 2004.

19. Yanokura M, Banno K, Iida M, Irie H, Umene K, Masuda K, Kobayashi Y, Tominaga E and Aoki D: MicroRNAS in endometrial cancer: Recent advances and potential clinical applications. EXCLI J 14: 190-198, 2015.

20. Lin J, Huang S, Wu S, Ding J, Zhao Y, Liang L, Tian Q, Zha R, Zhan R and He X: MicroRNA-423 promotes cell growth and regulates $\mathrm{G}(1) / \mathrm{S}$ transition by targeting $\mathrm{p} 21 \mathrm{Cip} 1 /$ Waf1 in hepatocellular carcinoma. Carcinogenesis 32: 1641-1647, 2011.

21. Zhao H, Gao A, Zhang Z, Tian R, Luo A, Li M, Zhao D, Fu L, Fu L, Dong JT and Zhu Z: Genetic analysis and preliminary function study of miR-423 in breast cancer. Tumour Biol 36: 4763-4771, 2015.

22. Volinia S, Galasso M, Sana ME, Wise TF, Palatini J, Huebner K and Croce CM: Breast cancer signatures for invasiveness and prognosis defined by deep sequencing of microRNA. Proc Natl Acad Sci USA 109: 3024-3029, 2012.

23. Dasari $S$ and Tchounwou PB: Cisplatin in cancer therapy: Molecular mechanisms of action. Eur J Pharmacol 740: 364-378, 2014.

24. Moxley KM and McMeekin DS: Endometrial carcinoma: A review of chemotherapy, drug resistance, and the search for new agents. Oncologist 15: 1026-1033, 2010.

25. Abdullah LN and Chow EK: Mechanisms of chemoresistance in cancer stem cells. Clin Transl Med 2: 3, 2013.

26. Zheng HC: The molecular mechanisms of chemoresistance in cancers. Oncotarget 8: 59950-59964, 2017.

27. Meng F, Henson R, Lang M, Wehbe H, Maheshwari S, Mendell JT, Jiang J, Schmittgen TD and Patel T: Involvement of human micro-RNA in growth and response to chemotherapy in human cholangiocarcinoma cell lines. Gastroenterology 130: 2113-2129, 2006

28. Yang H, Kong W, He L, Zhao JJ, O'Donnell JD, Wang J, Wenham RM, Coppola D, Kruk PA, Nicosia SV and Cheng JQ: MicroRNA expression profiling in human ovarian cancer: miR-214 induces cell survival and cisplatin resistance by targeting PTEN. Cancer Res 68: 425-433, 2008.

29. Kong W, He L, Coppola M, Esposito NN, Coppola D and Cheng JQ: MicroRNA-155 regulates cell survival, growth, and chemosensitivity by targeting FOXO3a in breast cancer. J Biol Chem 291: 22855, 2016.

30. Yu Z, Xu Z, Disante G, Wright J, Wang M, Li Y, Zhao Q, Ren T, Ju X, Gutman E, et al: miR-17/20 sensitization of breast cancer cells to chemotherapy-induced apoptosis requires Akt1. Oncotarget 5: 1083-1090, 2014.

31. Li L and Li W: Epithelial-mesenchymal transition in human cancer: Comprehensive reprogramming of metabolism, epigenetics, and differentiation. Pharmacol Ther 150: 33-46, 2015.

32. Gregory PA, Bert AG, Paterson EL, Barry SC, Tsykin A, Farshid G, Vadas MA, Khew-Goodall Y and Goodall GJ: The miR-200 family and miR-205 regulate epithelial to mesenchymal transition by targeting ZEB1 and SIP1. Nat Cell Biol 10: 593-601, 2008.

33. Xie Y, Naizabekov S, Chen Z and Tokay T: Power of PTEN/AKT: Molecular switch between tumor suppressors and oncogenes. Oncol Lett 12: 375-378, 2016.

34. Xu W, Yang Z, Zhou SF and Lu N: Posttranslational regulation of phosphatase and tensin homolog (PTEN) and its functional impact on cancer behaviors. Drug Des Devel Ther 8: 1745-1751, 2014.

35. Djordjevic B, Hennessy BT, Li J, Barkoh BA, Luthra R, Mills GB and Broaddus RR: Clinical assessment of PTEN loss in endometrial carcinoma: Immunohistochemistry outperforms gene sequencing. Mod Pathol 25: 699-708, 2012. 